\title{
EFFECT OF COMPOST, SULPHUR AND NITROGEN FERTILIZATION ON ESSENTIAL OIL PRODUCTION OF Achillea millefolium L. GROWN IN THE NEWLY RECLAIMED LAND
}

(Received: 2. 6. 2011)

\author{
By \\ E. M. Badawy, E. E. Aziz*, S. M. Nicola and H. F. Esmail* \\ Department of Ornamental Horticulture, Faculty of Agriculture, Cairo University. \\ * Cultivation and Production of Medicinal and Aromatic Plants Department, National \\ Research Centre, Cairo, Egypt.
}

\begin{abstract}
Field experiments were done in the Agricultural Experimental Station of the National Research Centre at Nubaria, Behira Governorate, west of the Nile Delta, Egypt using a drip irrigation system during the two successive seasons of 2007/2008 and 2008/2009, to investigate the effect of compost (10,20 and 30 ton/fed.), sulphur (100, 200 and $300 \mathrm{~kg} \mathrm{~S} / \mathrm{fed}$.) and nitrogen (100, 150 and $200 \mathrm{~kg} \mathrm{~N} / \mathrm{fed}$.) on the essential oil yield and its composition during the different growing cuts of Achillea millefolium L..

The essential oil of $A$. millefolium flowering head is characterized by containing $\beta$-pinene (33.4 $47.9 \%)$, sabinene $(7.4-14.7 \%)$, chamazulene $(5.6-21.9 \%)$ and $\beta$-caryophyllene $(0.8-8.0 \%)$. The results showed that the highest relative concentration of $\beta$-pinene $(47.9 \%)$ was obtained with the application of compost at the rate of $20 \mathrm{ton} / \mathrm{fed}$. combined with $300 \mathrm{~kg} \mathrm{~S} / \mathrm{fed}$. and $200 \mathrm{~kg} \mathrm{~N} / \mathrm{fed}$. . Further more, the application of 10 ton/fed. compost mixed with $300 \mathrm{~kg} \mathrm{~S} / \mathrm{fed}$. and $200 \mathrm{~kg} \mathrm{~N} / \mathrm{fed}$. gave the highest content of chamazulene $(21.9 \%)$ and $\beta$-caryophyllene $(8.0 \%)$ as well as it was accompanied by low amounts of $\beta$-pinene (33.4\%) and sabinene (7.4\%).

Thus, ammonium sulphate at $200 \mathrm{~kg} \mathrm{~N} / \mathrm{fed}$. combined with compost at 20 or $30 \mathrm{ton} / \mathrm{fed}$. and sulphur at $100 \mathrm{~kg} \mathrm{~S} / \mathrm{fed}$. was the most recommended treatment for increasing the essential oil productivity and quality of A. millefolium grown in the newly reclaimed sandy soil.
\end{abstract}

Key words: Achillea millefolium, compost, essential oil, fertilizer, newly reclaimed soil, nitrogen, sulphur.

\section{INTRODUCTION}

Achillea millefolium L. (Yarrow plant, Family: Asteraceae) is a widely distributed medicinal plant that has been used for over 3000 years (Mitich, 1990). Its name is said to go back to the Greek hero Achilles who used the herb to heal his soldier's bleeding wounds by stopping the flow of blood (Lawless, 1992). It is commonly known as Yarrow, milfoil, thousand leaf, green arrow and wound wort (Sweetman, 2002). It is native to Europe, North America, Southern Australia and Asia (Balbach, 1995). Now, it is widely distributed and cultivated in the temperate regions of the world (Blumenthal et al., 2000).

The essential oil is found in different levels in all above ground parts of the plant (Hofmann and Frtiz, 1993). The inflorescence of yarrow contains $0.2-0.5 \%$ of the essential oil, while the leaves and stem parts contain only 0.02 $0.07 \%$ (Hornok, 1974). The essential oil is characterized by containing sesquiterpenes with high amounts of chamazulene, $\beta$-caryophellene and geramacrene- $\mathrm{D}$, while the major components of monoterpenes were $\beta$-pinene, sabinene and 1,8 cineole (Aziz, 2004), $\alpha$-pinene and camphor (Ragažinskienè et al., 2005), myrcene, limonene and camphene (Rohloff et al., 2000) and borneol (Hofmann and Frtiz, 1993).

Yarrow in modern medicine is used in healing ointments applied to wounds (Sampson $e t$ al., 1997) and in reducing ulcer size (Nilforoushzadeh et al., 2008). It also has antitumor (Tozyo et al., 1994), antioxidant and antimicrobial activities (Candan et al., 2003), liver protective (Lin et al., 2002), gastric anti-secretory and gastro-protective activities (Baggio et al., 2002).

Achillea millefolium is an important medicinal plant, its multi-therapeutic and nutritional values have been established through years of traditional and scientific applications. Thus, plant production is 
developed due to the use of high yielding cultivars and enhanced consumption of organic and inorganic fertilizers.

In addition, the plant is perennial in nature, the nitrogen fertilizer applied at the time of initial growth may not be fully utilized by the plant and much of the excess nitrogen will be lost by leaching and/or volatilization. Nitrogen fertilizers, leaching losses of nitrogen on sandy soils vary from 30 to $70 \%$ depending on the type of applied fertilizers (Seng, 1986). These losses from the soil could be controlled by using elemental sulphur and organic fertilizer.

Sulphur is the fourth major plant nutrient next only to nitrogen, phosphorus and potassium. Sulphur is now; very much, a part of balanced fertilization (Gosh et al., 2000). It has been recognized to enhance plant growth through its compost, sulphur and nitrogen fertilizers on the essential oil production of Achillea millefolium $\mathrm{L}$. grown in the newly reclaimed land.

\section{MATERIALS AND METHODS}

The field experiments were carried out in the Agricultural Experimental Station of the National Research Centre at Nubaria, Behira Governorate west of the Nile Delta, using a drip irrigation system during the two successive seasons of $2007 / 2008$ and 2008/2009 to investigate the effect of sulphur, nitrogen and organic fertilizers on the essential oil yield and its composition of Achillea millefolium L. grown under the newly reclaimed sandy soil conditions.

The physical and chemical characteristics of the soil were determined according to Jackson (1973), and presented in Table (1).

Table (1): The physical and chemical properties of the experimental soil.

\begin{tabular}{|c|c|c|c|c|c|c|c|c|c|c|}
\hline \multirow[b]{2}{*}{ Season } & \multicolumn{10}{|c|}{ Physical properties } \\
\hline & $\begin{array}{c}\text { Very } \\
\text { coarse } \\
\text { sand }\end{array}$ & $\begin{array}{c}\text { Coarse } \\
\text { sand }\end{array}$ & $\begin{array}{c}\text { Medium } \\
\text { sand }\end{array}$ & $\begin{array}{l}\text { Fine } \\
\text { sand }\end{array}$ & $\begin{array}{l}\text { Very } \\
\text { fine } \\
\text { sand }\end{array}$ & Silt+Clay & Texture & & & \\
\hline $2007 / 2008$ & 34.77 & 35.31 & 0.48 & 15.98 & 12.45 & 1.01 & Sandy & & & \\
\hline \multirow[t]{4}{*}{$2008 / 2009$} & 31.52 & 39.25 & 0.43 & 16.57 & 11.31 & 0.92 & Sandy & & & \\
\hline & \multicolumn{10}{|c|}{ Chemical properties } \\
\hline & \multirow[t]{2}{*}{ pH } & E.C. & \multicolumn{8}{|c|}{$(\mathrm{meq} / \mathrm{l})$} \\
\hline & & $\left(\mathrm{dSm}^{-1}\right)$ & \multicolumn{4}{|c|}{ Cations } & \multicolumn{4}{|c|}{ Anions } \\
\hline & $(2.5: 1)$ & $(1: 1)$ & $\mathrm{Ca}^{++}$ & $\mathbf{M g}^{++}$ & $\mathrm{Na}^{+}$ & $\mathbf{K}^{+}$ & $\mathrm{CO}_{3}^{--}$ & $\mathrm{HCO}_{3}{ }^{-}$ & $\mathrm{Cl}^{-}$ & $\mathrm{So}_{4}$ \\
\hline $2007 / 2008$ & 7.71 & 0.2 & 0.8 & 0.4 & 0.8 & 0.1 & - & 0.8 & 0.1 & 0.3 \\
\hline $2008 / 2009$ & 7.96 & 0.4 & 1.5 & 1.0 & 1.3 & 0.2 & - & 2.1 & 1.0 & 0.9 \\
\hline
\end{tabular}

oxidization by soil micro- organisms to sulphuric acid; which in turn, lowers soil $\mathrm{pH}$, improves soil structure, and increases the availability of certain plant nutrients, notably phosphorus and several of micronutrients such as iron, manganese and zinc (Aziz and Taalab, 2004).

Application of organic fertilizer has various advantages such as increasing soil physical properties, water holding capacity and improving soil chemical properties (decreases soil $\mathrm{pH}$, increases cation exchange capacity and enhances most nutrients) that are important for plant growth (Snyman et al., 1998). The addition of organic sources could increase the yield through improving soil productivity and higher fertilizer use efficiency (Santhi and Selvakumari, 2000).

This work aimed to investigate the effect of
Maximum, minimum \& average air temperature and relative humidity of the Experimental Farm area during the growing period are presented in Table (2).

The layout of the experiment was split-split plot design. The main plots were assigned to compost doses $(10,20$ and 30 ton/fed.), the sub plots were assigned to sulphur fertilizer $(100,200$ and $300 \mathrm{~kg} \mathrm{~S} /$ fed.), which was added as agricultural sulphur $(99.9 \% \mathrm{~S})$; while the sub-sub plots were assigned to nitrogen fertilizer (100, 150 and $200 \mathrm{~kg} \mathrm{~N} / \mathrm{fed}$.), which was added as ammonium sulphate $(20.5 \% \mathrm{~N})$ in four doses during plant growth. Thus, the experiment included twenty seven treatments; each treatment was replicated three times and each replicate contained ten plants. 
Table (2): Monthly average of meteorological data of the Experimental Farm of Nubaria, Behira, Egypt during the years 2007, 2008 and 2009.

\begin{tabular}{|c|c|c|c|c|c|c|c|c|c|}
\hline \multicolumn{5}{|c|}{$2007 / 2008$ season } & \multicolumn{5}{|c|}{$2008 / 2009$ season } \\
\hline \multirow[b]{2}{*}{ Month } & \multicolumn{3}{|c|}{ Air temperature ${ }^{\circ} \mathrm{C}$} & \multirow[t]{2}{*}{ R.H.\% } & \multirow[b]{2}{*}{ Month } & \multicolumn{3}{|c|}{ Air temperature ${ }^{\circ} \mathrm{C}$} & \multirow[t]{2}{*}{ R.H.\% } \\
\hline & Max. & Min. & Average & & & Max & Min & Average & \\
\hline Sept. 07 & 30.02 & 22 & 27.02 & 61.1 & Sept. 08 & 30.63 & 20.47 & 25.6 & 67.8 \\
\hline Oct. 07 & 30.64 & 20.34 & 25.48 & 63.39 & Oct. 08 & 25.84 & 15.71 & 21.06 & 71.1 \\
\hline Nov. 07 & 25.61 & 15.37 & 20.5 & 56.86 & Nov. 08 & 23.9 & 13.27 & 18.77 & 70.23 \\
\hline Dec. 07 & 20.89 & 11.54 & 16.21 & 59.83 & Dec. 08 & 19.71 & 9.68 & 14.87 & 71.58 \\
\hline Jan. 08 & 16.06 & 7.48 & 11.9 & 73.61 & Jan. 09 & 18.81 & 8.03 & 13.52 & 70.26 \\
\hline Feb. 08 & 16.28 & 6.86 & 11.72 & 74.72 & Feb. 09 & 19.07 & 7.82 & 13.54 & 67.54 \\
\hline Mar. 08 & 23.42 & 10. & 16.94 & 66.58 & Mar. 09 & 19.55 & 8.65 & 14.19 & 64.29 \\
\hline Apr. 08 & 23.52 & 13.7 & 18.62 & 66.07 & Apr. 09 & 23.43 & 11.67 & 17.63 & 68.93 \\
\hline May 08 & 26.16 & 14.9 & 20.71 & 63.77 & May & 25.45 & 14.81 & 20.29 & 65.55 \\
\hline June 08 & 30.03 & 18.47 & 24.37 & 67.87 & June 09 & 29.9 & 19.77 & 24.93 & 65.43 \\
\hline July 08 & 29.94 & 21.1 & 25.58 & 70.29 & July 09 & 30.29 & 21.9 & 26.13 & 71.06 \\
\hline Aug. 08 & - & - & - & - & Aug. 09 & 30.35 & 20.9 & 25.68 & 69.32 \\
\hline Sept. 08 & - & - & - & - & Sept. 09 & 29.63 & 20.23 & 25.03 & 67.23 \\
\hline
\end{tabular}

Source: Central Laboratory for Agricultural Climate, Ministry of Agriculture, Cairo, Egypt.

The chemical characteristics of compost were determined according to Jackson ,1973 and presented in Table (3).

Table (3): The chemical analysis of compost during the seasons of $2007 / 2008$ and $2008 / 2009$.

\begin{tabular}{|l|c|c|}
\hline Character & 2007/2008 & 2008/2009 \\
\hline pH (1:10) & 7.74 & 7.54 \\
E.C. $\left(\mathbf{d S m}^{-\mathbf{1}}\right)(\mathbf{1 : 1 0})$ & 4.40 & 3.90 \\
Organic matter \% & 38.0 & 43.6 \\
Organic carbon \% & 22.1 & 25.3 \\
Total nitrogen \% & 1.20 & 1.30 \\
C/N ratio & $1: 18$ & $1: 20$ \\
Total phosphorus \% & 0.44 & 0.15 \\
Total potassium \% & 1.00 & 0.84 \\
Ash (\%) & 62.0 & 56.4 \\
\hline
\end{tabular}

Compost and sulphur were added during soil preparation, whereas nitrogen was added in four doses during plant growth. All treatments were fertilized with calcium superphosphate $(15.5 \%$ $\left.\mathrm{P}_{2} \mathrm{O}_{5}\right)$ at the rate of $100 \mathrm{~kg} \mathrm{P}_{2} \mathrm{O}_{5} / \mathrm{fed}$. and potassium sulphate $\left(48.5 \% \mathrm{~K}_{2} \mathrm{O}\right)$ at the rate of 100 $\mathrm{kg} \mathrm{K}_{2} \mathrm{O} /$ fed. during soil preparation.

Rhizomes of Achillea millefolium L. were obtained from the Experimental Farm of the Faculty of Pharmacy, Cairo University, Egypt. Divided plants of Achallea millefolium were planted, one plant every $50 \mathrm{~cm}$ adjacent to dripper lines, which were $75 \mathrm{~cm}$ apart, on the $3^{\text {rd }}$ October in $2007 / 2008$ season and the $19^{\text {th }}$ October in $2008 / 2009$ season. The replanting was done after two weeks from planting. Irrigation of the plants was done using drip system (10.5 1/day).

The flowering heads of Achillea millefolium were collected in the first cut at the $21^{s t}$ Feb. 2008 and the $10^{\text {th }}$ of March 2009, in the first and second seasons, respectively. The second cut was at the $10^{\text {th }}$ of April and the $5^{\text {th }}$ of May, then the third cut was at the $15^{\text {th }}$ of May and the $21^{\text {st }}$ of July and the fourth cut was at the $7^{\text {th }}$ of July and the $30^{\text {th }}$ of Sept. in the first and second seasons, respectively.

Essential oil percentages of the fresh flowering heads at different cuts were determined by hydro-distillation for 3 hours using Clevengertype apparatus, according to the Egyptian Pharmacopoeia (1984). Then, essential oil yield (ml/plant and l/fed.) was calculated. The obtained essential oil was dehydrated using anhydrous sodium sulphate, and then analyzed by using gas liquid chromatograph (GLC). The chromatograph apparatus was fitted with capillary column BPX$5,5 \%$ phenyl (reqiv.) polysillphenylene- siloxan $30 \mathrm{~m} \times 0.25 \mathrm{~mm}$ ID $\times 0.25 \mu \mathrm{m}$ film. Temperature program ramp increases with a rate of $8^{\circ} \mathrm{c} / \mathrm{min}$ from 70 to $200^{\circ} \mathrm{C}$. Flow rates of gases were nitrogen at $1 \mathrm{ml} / \mathrm{min}$., hydrogen at $30 \mathrm{ml} / \mathrm{min}$. and $330 \mathrm{ml} / \mathrm{min}$. for air. Detector and injector temperatures were $300^{\circ} \mathrm{C}$ and $250^{\circ} \mathrm{C}$, respectively. The obtained chromatogram and report of GC 
analysis for each sample were analyzed to calculate the percentage of main components of volatile oil. The area of each peak was first calculated by an automatic integrator. The areas were then summed. The total area of the peaks represented the whole sample. The percentage of each component was the ratio between its peak areas to the total peak area, multiplied by 100 . The identification of these compounds was achieved by matching their retention times with those of authentic samples injected at the same conditions.

The data recorded were analyzed using the MSTAT-C program (MSTAT, 1988). Least significant difference test (LSD) was applied at 0.05 probability level to compare mean treatments.

\section{RESULTS AND DISCUSSION}

The data presented in Tables $(4,5,6$ and 7) showed the effect of compost, sulphur and nitrogen fertilizers on flowering heads and essential oil production during the first and second seasons.

\subsection{Effect of compost}

The application of compost at 30 ton/fed. recorded the highest increase in the essential oil percentages $(0.069,0.137,0.184$ and $0.172 \%$ in the $1^{\text {st }}, 2^{\text {nd }}, 3^{\text {rd }}$ and $4^{\text {th }}$ cuts, respectively) in the $1^{\text {st }}$ season and reached the maximum value $(0.184 \%$ in the $3^{\text {rd }}$ cut $\left(15^{\text {th }}\right.$ May)) (Table, 4). The same trend was found in the $2^{\text {nd }}$ season (Table, 5), while the maximum value $(0.170 \%)$ was obtained from the $4^{\text {th }}$ cut $\left(21^{\text {st }}\right.$ July $)$.

Table (6) showed that, adding 20 ton compost/fed. gave the highest fresh yield in both seasons.

Moreover, the addition of compost at 30 ton/fed. gave the greatest mean values of essential oil total yield as shown in Table (7) $(0.31 \mathrm{ml} /$ plant and $3.50 \mathrm{~L} / \mathrm{fed}$. in the $1^{\text {st }}$ season) and $(0.23$ $\mathrm{ml} / \mathrm{plant}$ and $2.55 \mathrm{~L} / \mathrm{fed}$. in the $2^{\text {nd }}$ season). It was observed that, there were no significant differences between compost at 30 and 20 ton/fed. on essential oil total yield ( $\mathrm{ml} /$ plant and L/fed.) in both seasons.

The increase in flowering head essential oil production with the increase of compost levels might be due to its superior and improved role to supply the growing plants with the required micro and macro nutrient elements. Naturally, these elements play an important role in the metabolic processes like photosynthesis, respiration and carbohydrate synthesis (Abo El-Seoud et al., 1997). It is claimed that the precursor of essential oil could be resulted from the degradation of carbohydrates and proteins (Guenther, 1961). Positive effects of fertilizer on secondary metabolites have been reported by several investigators for a variety of medicinal and aromatic species, Aziz (2004) on Achillea millefolium, Ali (2009) on Foeniculum vulgare, Ateia et al. (2009) on Thymus vulgaris, El-Sayed et al. (2009) on Artemisia dracunculus and Hendawy et al. (2010) on Thymus vulgaris.

\subsection{Effect of sulphur fertilizer}

In the $1^{\text {st }}$ season (Table, 4), the addition of agricultural sulphur at $300 \mathrm{~kg} \mathrm{~S} / \mathrm{fed}$. gave the greatest increase of essential oil percentages $\left(0.066,0.135,0.183\right.$ and $0.175 \%$ in the $1^{s t}, 2^{\text {nd }}, 3^{\text {rd }}$ and $4^{\text {th }}$ cut, respectively). The highest dose of sulphur (300 kg S/fed.) resulted in the greatest fresh yield in both seasons (Table 6) and produced the highest mean values of essential oil total yield as shown in Table (7) $(0.34 \mathrm{ml} /$ plant and 3.77 L/fed.). The results of the $2^{\text {nd }}$ season (Tables, 5 and 7) gave similar trend.

The enhancement in essential oil yield may be attributed to that sulphur is recognized to enhance plant growth in arid and alkaline soils through oxidation by soil microorganisms that convert the sulphur to sulphuric acid which in turn lower soil $\mathrm{pH}$, improves soil structure, and increases the availability of certain plant nutrients, notably phosphorus and of micronutrients (iron, manganese, and zinc) (Stamford et al., 2003). As well as sulphur participates in various coenzymes, which have an important role in essential oil synthesis (Haneklaus et al., 1997). The results agreed with other earlier studies on Allium cepa (Lancaster et al., 2001), Cynara cardunculus (Rodrigo et al., 2005), and Dracocephalum moldavica (Aziz et al., 2010).

\subsection{Effect of nitrogen fertilizer}

The highest rate of nitrogen $(200 \mathrm{~kg} \mathrm{~N} / \mathrm{fed}$.) resulted in the greatest increment in flowering head essential oil percentages in the $1^{\text {st }}$ season $\left(0.138,0.183\right.$ and $0.172 \%$ in the $2^{\text {nd }}, 3^{\text {rd }}$ and $4^{\text {th }}$ cut, respectively) as shown in Table (4) and in the $2^{\text {nd }}$ season $\left(0.077,0.136\right.$ and $0.169 \%$ in the $1^{\text {st }}, 3^{\text {rd }}$ and $4^{\text {th }}$ cut, respectively) as shown in Table (5).

Results in Tables (6) revealed that, Treating plants with $200 \mathrm{~kg} \mathrm{~N} / \mathrm{fed}$. gave the greatest fresh yield in both seasons. At the same time, this level of nitrogen resulted in the highest increase in flowering heads essential oil total yield ( 0.34 $\mathrm{ml} / \mathrm{plant}$ and $3.85 \mathrm{l} / \mathrm{fed}$. in the $1^{\text {st }}$ season) and $\left(0.26 \mathrm{ml} /\right.$ plant and $2.95 \mathrm{l} / \mathrm{fed}$. in the $2^{\text {nd }}$ season) as illustrated in Table (7). 
Table (4): Effect of compost, sulphur and nitrogen fertilizers on essential oil (\%) of Achillea millefolium flowering heads during 2007/2008 season.

\begin{tabular}{|c|c|c|c|c|c|c|c|c|c|}
\hline \multirow{3}{*}{$\begin{array}{c}\mathbf{A}^{*} \mathbf{B} * \mathbf{C} \\
\text { Interaction }\end{array}$} & \multicolumn{9}{|c|}{$1^{\text {st }}$ cut } \\
\hline & \multicolumn{9}{|c|}{ Sulphur (kg S/fed.) } \\
\hline & \multicolumn{3}{|c|}{100} & \multicolumn{3}{|c|}{200} & \multicolumn{3}{|c|}{300} \\
\hline \multirow{2}{*}{$\begin{array}{l}\text { Compost } \\
\text { (ton/fed.) }\end{array}$} & \multicolumn{9}{|c|}{ Nitrogen (kg N/fed.) } \\
\hline & 100 & 150 & 200 & 100 & 150 & 200 & 100 & 150 & 200 \\
\hline 10 & 0.052 & 0.055 & 0.056 & 0.053 & 0.057 & 0.060 & 0.056 & 0.062 & 0.065 \\
\hline 20 & 0.054 & 0.057 & 0.060 & 0.057 & 0.059 & 0.063 & 0.061 & 0.063 & 0.067 \\
\hline 30 & 0.059 & 0.065 & 0.065 & 0.064 & 0.069 & 0.076 & 0.066 & 0.074 & 0.081 \\
\hline \multirow[t]{4}{*}{ Mean } & \multicolumn{3}{|c|}{$\begin{array}{l}\text { Compost } \\
\text { (ton/fed.) }\end{array}$} & \multicolumn{2}{|c|}{$\begin{array}{l}\text { Sulphur } \\
\text { (kg S/fed.) }\end{array}$} & \multicolumn{3}{|c|}{$\begin{array}{l}\text { Nitrogen } \\
\text { (kg N/fed.) }\end{array}$} & \\
\hline & 10 & 0.057 & & 100 & 0.058 & & 100 & 0.058 & \\
\hline & 20 & 0.060 & & 200 & 0.062 & & 150 & 0.062 & \\
\hline & 30 & 0.069 & & 300 & 0.066 & & 200 & 0.066 & \\
\hline \multirow{2}{*}{$\begin{array}{c}\text { LSD at } \\
5 \% \\
\end{array}$} & $\mathbf{A}$ & $\overline{\mathbf{B}}$ & $\bar{C}$ & $\overline{A B}$ & $\overline{A C}$ & $\overline{B C}$ & $\mathbf{A B C}$ & & \\
\hline & 0.001 & 0.001 & N.S & 0.001 & N.S & N.S & N.S & & \\
\hline & \multicolumn{9}{|c|}{$2^{\text {nd }}$ cut } \\
\hline 10 & 0.098 & 0.122 & 0.123 & 0.103 & 0.125 & 0.134 & 0.113 & 0.129 & 0.139 \\
\hline 20 & 0.124 & 0.127 & 0.133 & 0.127 & 0.130 & 0.139 & 0.129 & 0.137 & 0.144 \\
\hline 30 & 0.125 & 0.135 & 0.139 & 0.129 & 0.138 & 0.143 & 0.131 & 0.141 & 0.150 \\
\hline \multirow[t]{4}{*}{ Mean } & \multicolumn{2}{|c|}{$\begin{array}{l}\text { Compost } \\
\text { (ton/fed.) }\end{array}$} & & \multicolumn{2}{|c|}{$\begin{array}{l}\text { Sulphur } \\
\text { (kg S/fed.) }\end{array}$} & \multicolumn{3}{|c|}{$\begin{array}{l}\text { Nitrogen } \\
\text { (kg N/fed.) }\end{array}$} & \\
\hline & 10 & 0.121 & & 100 & 0.125 & & 100 & 0.120 & \\
\hline & 20 & 0.132 & & 200 & 0.130 & & 150 & 0.132 & \\
\hline & 30 & 0.137 & & 300 & 0.135 & & 200 & 0.138 & \\
\hline \multirow{3}{*}{$\begin{array}{c}\text { LSD at } \\
5 \%\end{array}$} & $\overline{\mathbf{A}}$ & $\mathbf{B}$ & $\bar{C}$ & $\overline{A B}$ & $\overline{A C}$ & $\mathbf{B C}$ & $\mathbf{A B C}$ & & \\
\hline & 0.001 & 0.001 & 0.001 & 0.001 & 0.001 & 0.001 & 0.001 & & \\
\hline & \multicolumn{8}{|c|}{$3^{\text {rd }}$ cut } & \\
\hline 10 & 0.157 & 0.158 & 0.165 & 0.163 & 0.170 & 0.176 & 0.166 & 0.174 & 0.180 \\
\hline 20 & 0.166 & 0.170 & 0.178 & 0.172 & 0.177 & 0.184 & 0.177 & 0.181 & 0.186 \\
\hline 30 & 0.171 & 0.178 & 0.184 & 0.173 & 0.183 & 0.187 & 0.184 & 0.193 & 0.207 \\
\hline \multirow[t]{4}{*}{ Mean } & \multicolumn{2}{|c|}{$\begin{array}{l}\text { Compost } \\
\text { (ton/fed.) }\end{array}$} & & $\begin{array}{l}\text { Sulphur } \\
\text { (kg S/fed }\end{array}$ & & & $\begin{array}{l}\text { Nitroge } \\
\text { (kg N/fe }\end{array}$ & & \\
\hline & 10 & 0.168 & & 100 & 0.170 & & 100 & 0.170 & \\
\hline & 20 & 0.177 & & 200 & 0.176 & & 150 & 0.176 & \\
\hline & 30 & 0.184 & & 300 & 0.183 & & 200 & 0.183 & \\
\hline LSD at & $\mathbf{A}$ & B & $\mathrm{C}$ & $\overline{\mathbf{A B}}$ & $\mathbf{A C}$ & BC & $\mathbf{A B C}$ & & \\
\hline $5 \%$ & 0.001 & 0.001 & 0.001 & 0.001 & 0.001 & 0.001 & 0.001 & & \\
\hline & & & & & $4^{\text {th }}$ cut & & & & \\
\hline 10 & 0.144 & 0.151 & 0.157 & 0.154 & 0.156 & 0.158 & 0.161 & 0.170 & 0.174 \\
\hline 20 & 0.155 & 0.159 & 0.163 & 0.162 & 0.165 & 0.174 & 0.168 & 0.176 & 0.183 \\
\hline 30 & 0.160 & 0.166 & 0.173 & 0.162 & 0.170 & 0.179 & 0.172 & 0.179 & 0.188 \\
\hline Mean & $\begin{array}{l}\text { Compo } \\
\text { (ton/fed }\end{array}$ & & & $\begin{array}{l}\text { Sulphur } \\
\text { (kg S/fed }\end{array}$ & & & $\begin{array}{l}\text { Nitroge } \\
(k g \text { N/fe }\end{array}$ & & \\
\hline & 10 & 0.158 & & 100 & 0.159 & & 100 & 0.160 & \\
\hline & 20 & 0.167 & & 200 & 0.164 & & 150 & 0.166 & \\
\hline & 30 & 0.172 & & 300 & 0.175 & & 200 & 0.172 & \\
\hline LSD at & $\overline{\mathbf{A}}$ & B & $\bar{C}$ & $\overline{A B}$ & $\overline{A C}$ & BC & $\mathbf{A B C}$ & & \\
\hline $5 \%$ & 0.001 & 0.001 & 0.001 & 0.001 & 0.001 & 0.001 & 0.002 & & \\
\hline
\end{tabular}


Table (5): Effect of compost, sulphur and nitrogen fertilizers on essential oil (\%) of Achillea millefolium flowering heads during 2008/2009 season.

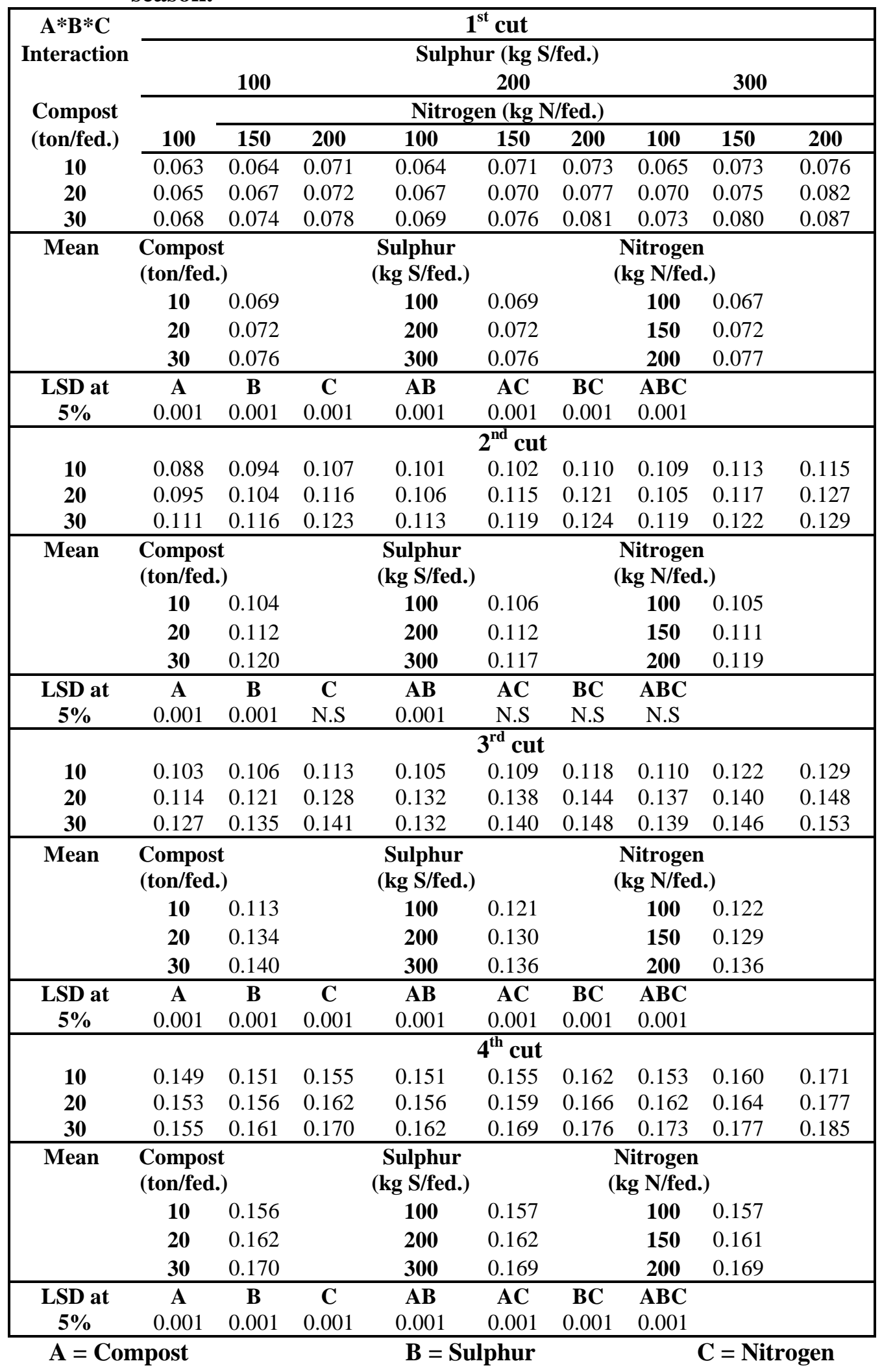


Table (6): Effect of compost, sulphur and nitrogen fertilizers on total fresh yield (g/plant and ton/fed.) of Achillea millefolium flowering heads during 2007/2008 and 2008/2009 seasons.

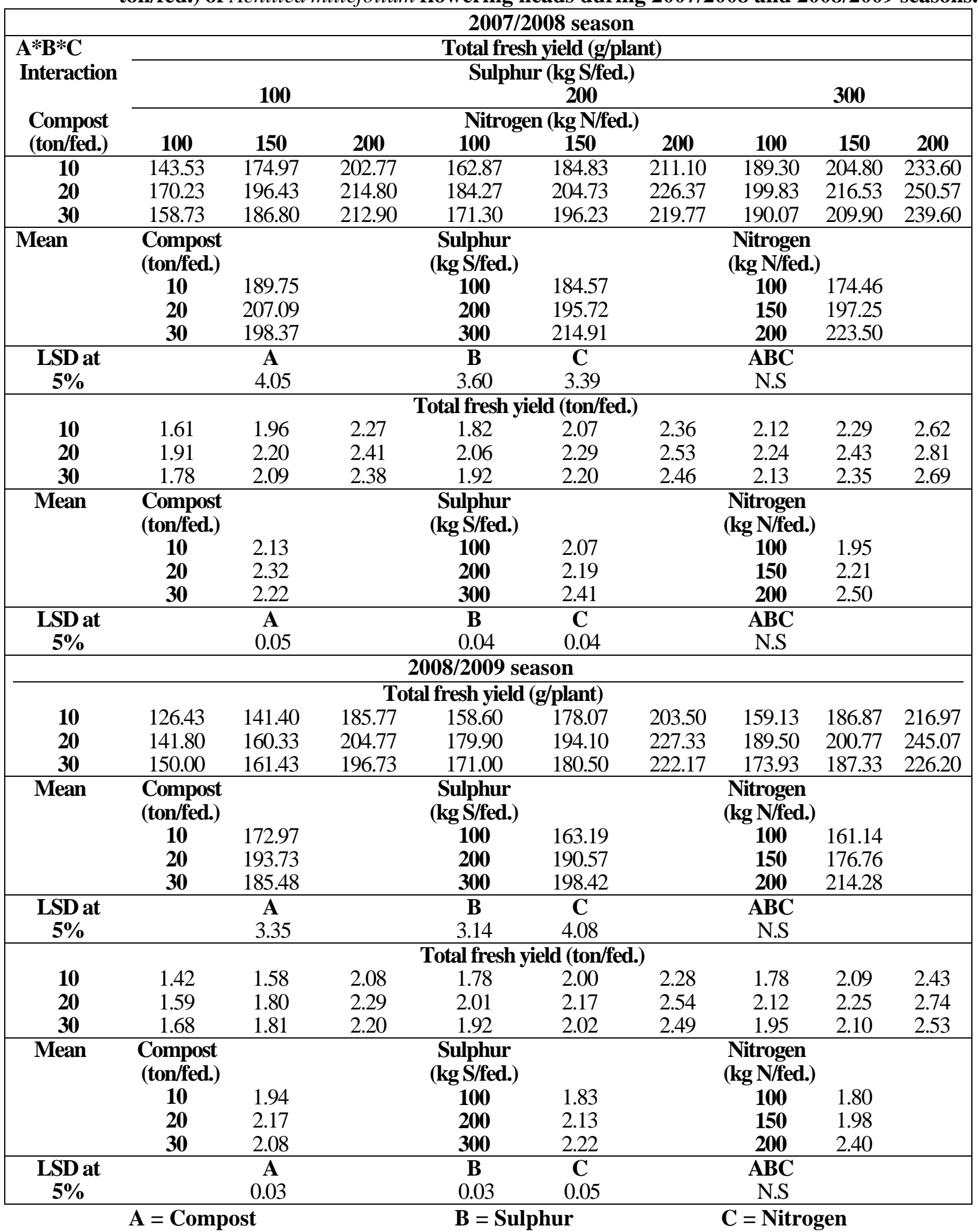


Table (7): Effect of compost, sulphur and nitrogen fertilizers on essential oil total yield ( $\mathrm{ml} /$ plant and $1 /$ fed.) of Achillea millefolium flowering heads during $2007 / 2008$ and $2008 / 2009$ seasons.

\begin{tabular}{|c|c|c|c|c|c|c|c|c|c|}
\hline \multirow{6}{*}{$\begin{array}{c}\mathbf{A}^{*} \mathbf{B} * \mathbf{C} \\
\text { Interaction } \\
\text { Compost } \\
\text { (ton/fed.) }\end{array}$} & \multicolumn{9}{|c|}{$2007 / 2008$ season } \\
\hline & \multicolumn{9}{|c|}{ Total yield (ml/plant) } \\
\hline & \multicolumn{9}{|c|}{ Sulphur (kg S/fed.) } \\
\hline & \multicolumn{3}{|c|}{100} & \multicolumn{3}{|c|}{200} & \multicolumn{3}{|c|}{300} \\
\hline & \multicolumn{9}{|c|}{ Nitrogen (kg N/fed.) } \\
\hline & 100 & 150 & 200 & 100 & $150^{\circ}$ & 200 & 100 & 150 & 200 \\
\hline 10 & 0.19 & 0.24 & 0.29 & 0.22 & 0.27 & 0.31 & 0.27 & 0.31 & 0.36 \\
\hline 20 & 0.24 & 0.28 & 0.32 & 0.27 & 0.30 & 0.35 & 0.30 & 0.34 & 0.40 \\
\hline 30 & 0.23 & 0.29 & 0.33 & 0.26 & 0.31 & 0.35 & 0.30 & 0.35 & 0.41 \\
\hline \multirow[t]{4}{*}{ Mean } & \multicolumn{2}{|c|}{$\begin{array}{l}\text { Compost } \\
\text { (ton/fed.) }\end{array}$} & & \multicolumn{2}{|c|}{$\begin{array}{c}\text { Sulphur } \\
\text { (kg S/fed.) }\end{array}$} & \multicolumn{3}{|c|}{$\begin{array}{l}\text { Nitrogen } \\
\text { (kg N/fed.) }\end{array}$} & \\
\hline & 10 & 0.27 & & 100 & 0.27 & & 100 & 0.25 & \\
\hline & 20 & 0.31 & & 200 & 0.29 & & 150 & 0.30 & \\
\hline & 30 & 0.31 & & 300 & 0.34 & & 200 & 0.34 & \\
\hline LSD at & $\mathbf{A}$ & B & $\mathbf{C}$ & AB & $\mathbf{A C}$ & BC & $\mathrm{ABC}$ & & \\
\hline \multirow[t]{2}{*}{$5 \%$} & 0.01 & 0.01 & 0.01 & N.S & N.S & N.S & N.S & & \\
\hline & \multicolumn{9}{|c|}{ Total yield (l/fed.) } \\
\hline 10 & 2.10 & 2.68 & 3.19 & 2.50 & 2.99 & 3.43 & 3.04 & 3.50 & 4.00 \\
\hline 20 & 2.67 & 3.18 & 3.54 & 3.02 & 3.41 & 3.87 & 3.39 & 3.80 & 4.44 \\
\hline 30 & 2.60 & 3.20 & 3.73 & 2.87 & 3.42 & 3.90 & 3.33 & 3.87 & 4.59 \\
\hline \multirow[t]{4}{*}{ Mean } & \multicolumn{2}{|c|}{$\begin{array}{l}\text { Compost } \\
\text { (ton/fed.) }\end{array}$} & & \multicolumn{2}{|c|}{$\begin{array}{l}\text { Sulphur } \\
\text { (kg S/fed.) }\end{array}$} & \multicolumn{3}{|c|}{$\begin{array}{l}\text { Nitrogen } \\
\text { (kg N/fed.) }\end{array}$} & \\
\hline & 10 & 3.05 & & 100 & 2.99 & & 100 & 2.83 & \\
\hline & 20 & 3.48 & & 200 & 3.27 & & 150 & 3.34 & \\
\hline & 30 & 3.50 & & 300 & 3.77 & & 200 & 3.85 & \\
\hline LSD at & $\mathbf{A}$ & $\overline{\mathbf{B}}$ & $\bar{C}$ & $\overline{\mathrm{AB}}$ & $\mathrm{AC}$ & $\overline{\mathrm{BC}}$ & $\overline{\mathrm{ABC}}$ & & \\
\hline \multirow[t]{2}{*}{$5 \%$} & 0.06 & 0.06 & 0.06 & N.S & N.S & N.S & N.S & & \\
\hline & \multicolumn{9}{|c|}{ 2008/2009 season } \\
\hline & \multicolumn{9}{|c|}{ Total yield (ml/plant) } \\
\hline 10 & 0.12 & 0.14 & 0.20 & 0.16 & 0.18 & 0.23 & 0.17 & 0.21 & 0.26 \\
\hline 20 & 0.14 & 0.17 & 0.24 & 0.20 & 0.23 & 0.28 & 0.21 & 0.24 & 0.32 \\
\hline 30 & 0.17 & 0.19 & 0.25 & 0.20 & 0.22 & 0.29 & 0.21 & 0.23 & 0.30 \\
\hline Mean & $\begin{array}{l}\text { Comp } \\
\text { (ton/f }\end{array}$ & & & $\begin{array}{r}\text { Sulphı } \\
\text { (kg S/ }\end{array}$ & $\begin{array}{l}\text { red.) } \\
\text { ed. }\end{array}$ & & $\begin{array}{l}\text { itroge } \\
\text { g N/fe }\end{array}$ & & \\
\hline & 10 & 0.18 & & 100 & 0.18 & & 100 & 0.17 & \\
\hline & 20 & 0.23 & & 200 & 0.22 & & 150 & 0.20 & \\
\hline & 30 & 0.23 & & 300 & 0.24 & & 200 & 0.26 & \\
\hline LSD at & $\mathbf{A}$ & $\overline{\mathbf{B}}$ & $\mathbf{C}$ & $\overline{A B}$ & $\mathrm{AC}$ & $\overline{B C}$ & $\overline{\mathrm{ABC}}$ & & \\
\hline $5 \%$ & 0.01 & 0.01 & 0.01 & 0.01 & N.S & N.S & N.S & & \\
\hline & & & & Tot & I yield & $(\bar{l} /$ fed. $)$ & & & \\
\hline 10 & 1.29 & 1.53 & 2.27 & 1.75 & 2.04 & 2.55 & 1.86 & 2.34 & 2.89 \\
\hline 20 & 1.58 & 1.92 & 2.71 & 2.20 & 2.52 & 3.18 & 2.37 & 2.69 & 3.60 \\
\hline 30 & 1.86 & 2.11 & 2.77 & 2.18 & 2.44 & 3.20 & 2.34 & 2.62 & 3.41 \\
\hline Mean & $\begin{array}{l}\mathrm{Comp} \\
\text { (ton/f }\end{array}$ & & & $\begin{array}{c}\text { Sulph } \\
(\mathrm{kg} \mathrm{S} / \mathrm{f}\end{array}$ & & & $\begin{array}{l}\text { jitrog } \\
\text { g N/f }\end{array}$ & & \\
\hline & 10 & 2.06 & & 100 & 2.00 & & 100 & 1.94 & \\
\hline & 20 & 2.53 & & 200 & 2.45 & & 150 & 2.25 & \\
\hline & 30 & 2.55 & & 300 & 2.68 & & 200 & 2.95 & \\
\hline LSD at & $\overline{\mathbf{A}}$ & $\mathbf{B}$ & $\mathbf{C}$ & $\mathbf{A B}$ & $\mathrm{AC}$ & $\mathbf{B C}$ & $\mathbf{A B C}$ & & \\
\hline $5 \%$ & 0.04 & 0.05 & 0.06 & 0.09 & N.S & N.S & N.S & & \\
\hline
\end{tabular}


The increment in essential oil percentage by application of the nitrogen fertilizer may be due to that nitrogen is a constituent of several precursors to essential oil constituents (Ram et al., 2006) and could be expected to increase essential oil production. These results are in accordance with those obtained by Aziz (2004) on Achillea millefolium, who showed that $50 \mathrm{~kg} \mathrm{~N} / \mathrm{fed}$. as ammonium sulphate was the most effective treatment for increasing flowering heads essential yield, as well as Ram et al. (2006) on Mentha arvensis, who found that essential oil yield was significantly influenced by the application of 200 $\mathrm{kg} \mathrm{N} / \mathrm{ha}$ in the form of urea. Sifola and Barbieri (2006) on Ocimum basilicum reported that $300 \mathrm{~kg}$ $\mathrm{N} / \mathrm{ha}$ as ammonium nitrate increased leaf essential oil percentage and yield. Zheljazkov et al. (2008) on Ocimum basilicum demonstrated that essential oil yield was maximized at $\mathrm{N}$ fertilization of $60 \mathrm{~kg}$ $\mathrm{N} / \mathrm{ha}$ as ammonium nitrate and Abbaszadeh et al. (2009) on Melissa officinalis showed that the highest essential oil percentage and yield was obtained under the application of $60 \mathrm{~kg} \mathrm{~N} / \mathrm{ha}$ as urea.

\subsection{Effect of the interaction between compost, sulphur or nitrogen fertilizers}

The data in Tables (4 and 5) showed that, the application of compost at 30 ton/fed. combined with $300 \mathrm{~kg} \mathrm{~S} / \mathrm{fed}$. and $200 \mathrm{~kg} \mathrm{~N} / \mathrm{fed}$. gave the highest percentages of flowering heads essential oil $\left(0.150,0.207\right.$ and $0.188 \%$ in the $2^{\text {nd }}, 3^{\text {rd }}$ and $4^{\text {th }}$ cuts of the $1^{\text {st }}$ season, respectively) as well as $\left(0.087,0.153\right.$ and $0.185 \%$ in the $1^{s t}, 3^{r d}$ and $4^{\text {th }}$ cuts of the $2^{\text {nd }}$ season, respectively).

\subsection{Essential oil constituents}

The results in Table (8) showed that the essential oil of Achillea millefolium flowering heads was characterized by containing monoterpene hydrocarbons and the major components were $\beta$-pinene $(33.4-47.9 \%)$ and sabinene $(7.4-14.7 \%)$. Whereas $\beta$-pinene was the prevalent monoterpene of the plant. Chamazulene (5.6 - 21.9\%) and $\beta$-caryophyllene $(0.8-8.0 \%)$ were the principal sesquiterpenes. Oxygen containing terpenes were found only in small amounts and 1,8-cineole $(1.7-5.4 \%)$ was the most prominent oxygen-containing monoterpenes. These results are in agreement with those reported by Hofmann and Fritz (1993) as well as Grth and Czygan (1999).

The data in Table (8) and in Figures (1 and 2) showed that the highest relative concentration of $\beta$-pinene $(47.9 \%)$ was obtained with the application of compost at the rate of 20 ton/fed. combined with sulphur at $300 \mathrm{~kg} \mathrm{~S} / \mathrm{fed}$. and ammonium sulphate at $200 \mathrm{~kg} \mathrm{~N} / \mathrm{fed}$.. Further more, the application of 10 ton/fed. compost mixed with $300 \mathrm{~kg} \mathrm{~S} / \mathrm{fed}$. and $200 \mathrm{~kg} \mathrm{~N} / \mathrm{fed}$. gave the highest content of chamazulene $(21.9 \%)$ and $\beta$-caryophyllene $(8.0 \%)$ as well as it was accompanied by lower amounts of $\beta$-pinene (33.4 $\%)$ and sabinene $(7.4 \%)$. Moreover, variable effects either ascending or descending were noticed in the content of some components of Achillea oil as affected with different fertilization treatments.

The positive influence of different fertilization treatments on the essential oil constiuents was reported by many investigators, Aziz (2004) on Achillea millefolium showed that the application of ammonium sulphate at $50 \mathrm{kgN} / \mathrm{fed}$. combined with $15 \mathrm{ton} / \mathrm{fed}$. of poultry manure gave the highest content of chamazulene $(39.57 \%), \quad \beta$-caryophyllene $(20.24 \%)$ and geramacrene -D (14.58 \%). Zheljazkov et al. (2008) on Ocimum basilicum L. demonstrated that 50 to $60 \mathrm{~kg} \mathrm{~N} / \mathrm{ha}$ as ammonium nitrate maximized linalool and eugenol yields. El-Sayed et al. (2009) on Artemisia dracunculus L. stated that $60 \mathrm{~m}^{3} / \mathrm{fed}$. cattle manure was the most effective treatment in limonene content. Hendawy et al. (2010) on Thymus vulgaris pointed out that the highest value of oxygenated compounds was obtained from plants received $20 \mathrm{~L} / \mathrm{fed}$. of compost tea $+150 \mathrm{~kg} / \mathrm{fed}$. rock phosphate. More over Aziz et al. (2010) reported that ammonium sulphate at $100 \mathrm{~kg} \mathrm{~N} / \mathrm{ha}$ increased the relative concentration of neral, geranyl acetate, and geraniol of Dracocephalum moldavica.

It could be concluded that ammonium sulphate may become suitable for development of a slow fertilizer when combined with compost, and agricultural sulphur. Thus, ammonium sulphate at $200 \mathrm{~kg} \mathrm{~N} / \mathrm{fed}$. combined with 20 or 30 ton/fed. of compost and sulphur at $100 \mathrm{~kg} \mathrm{~S} / \mathrm{fed}$. was the most suitable treatment for increasing the productivity and quality of Achillea millefolium L. grown in the newly reclaimed land.

\section{Acknowledgement}

Special appreciation to Prof. Dr. Salah Sayed Ahmed, Researcher Professor of Medicinal and Aromatic plants, at the National Research Centre, for his help during the preparation of this work. 
Table (8): Effect of compost, sulphur and nitrogen fertilizers on essential oil composition of Achillea millefolium plants during 2007/2008 season.

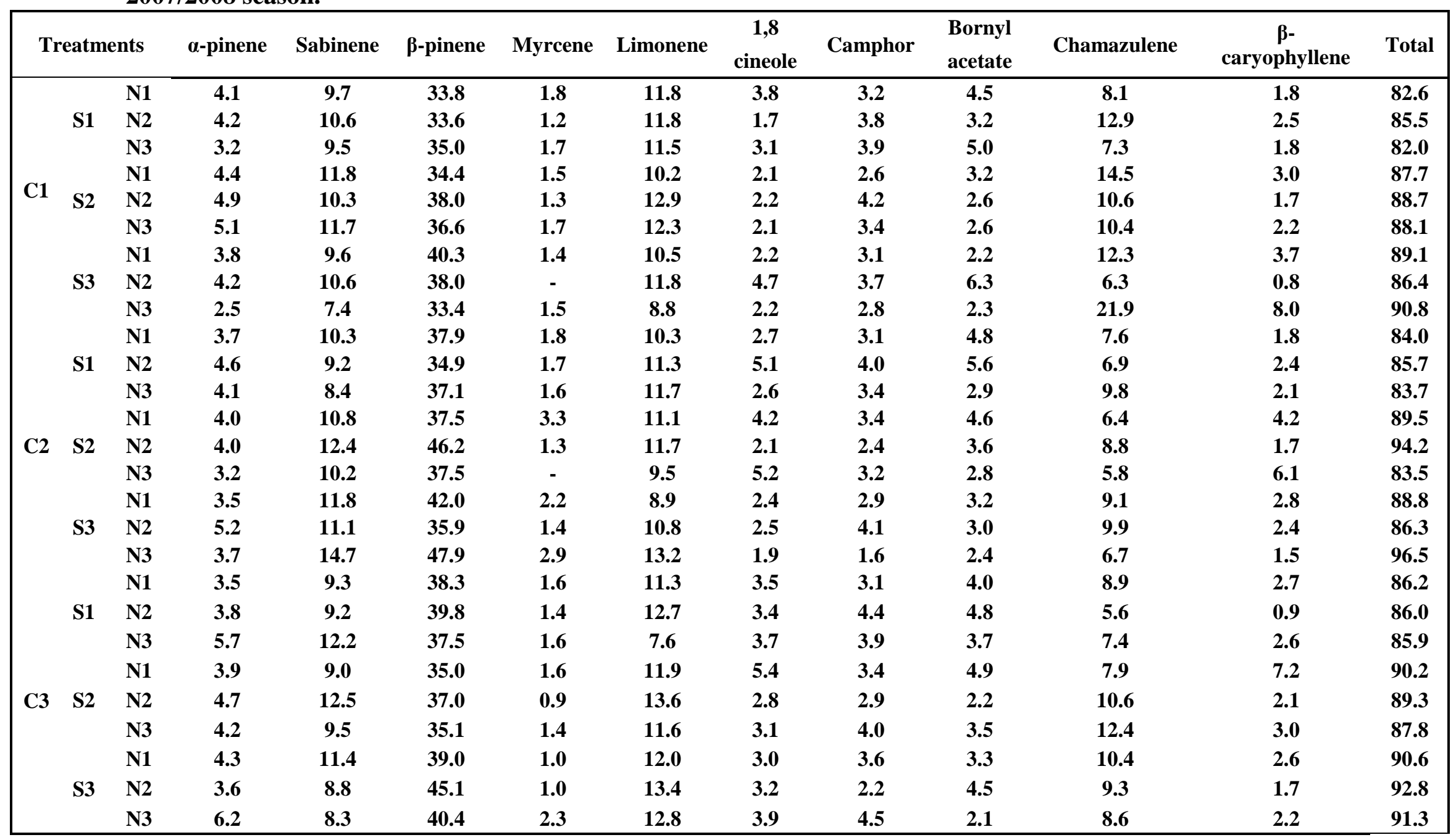




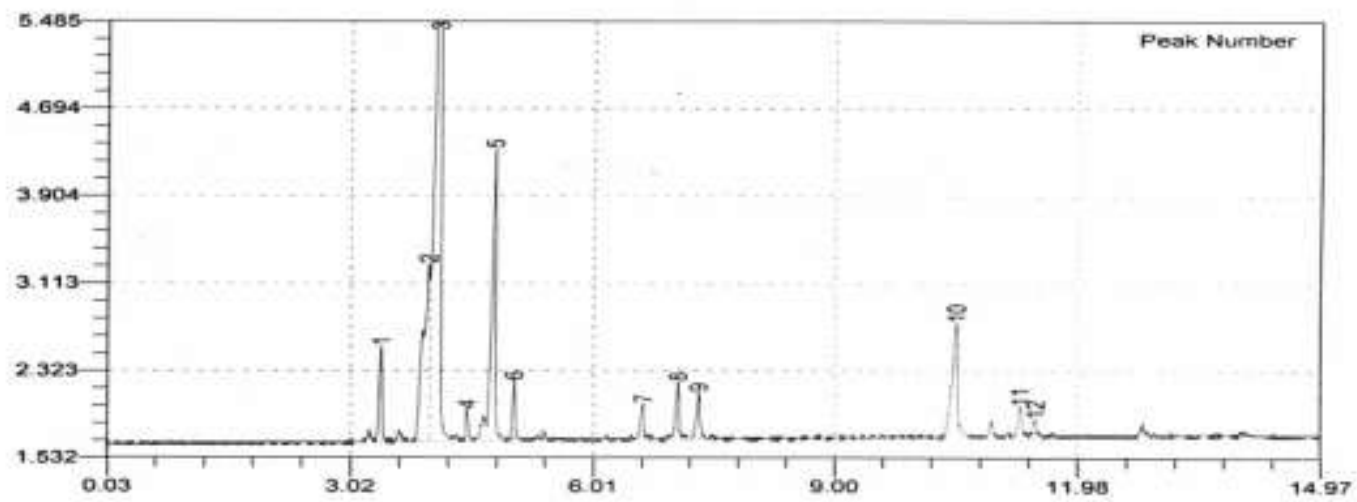

Fig. (1): GLC Chromatogram of the essential oil of flowering heads of Achillea millefolium plants fertilized with 20 ton/fed. compost, $300 \mathrm{~kg}$ S/fed. and $200 \mathrm{~kg} \mathrm{~N} / \mathrm{fed}$.

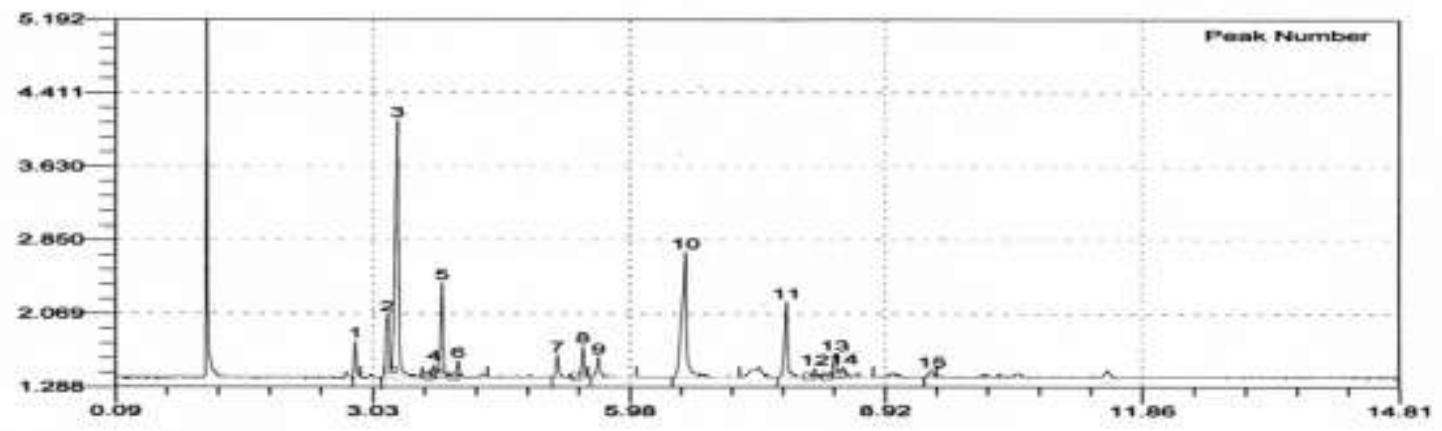

Fig.(2): GLC Chromatogram of the essential oil of flowering heads of Achillea millefolium plants fertilized with 10 ton/fed. compost, $300 \mathrm{~kg} \mathrm{S/fed.} \mathrm{and} 200 \mathrm{~kg} \mathrm{~N} / \mathrm{fed}$.

\section{REFERENCES}

Abbaszadeh B., Farahani H.A., Valadabadi S.A. and Darvishi H.H. (2009). Nitrogenous fertilizer influence on quantity and quality values of balm (Melissa officinalis L.). Journal of Agricultural Extension and Rural Development, 1(1): 031-033.

Abo El-Seoud M.A., Abdel-Sabour M.F. and Omer E.A. (1997). Productivity of roselle (Hibiscus sabdariffa L.) plant as affected by organic waste composts added to sandy soil. Bull. Nrc, Egypt, 22(4): 495-505.

Ali H.M.H. (2009). Effect of biofertilization on growth, yield and constituents of fennel plant. Ph.D. Thesis, Fac. Agric., Cairo Univ.

Ateia E.M., Osman Y.A.H. and Meawad A.E.A. (2009). Effect of organic fertilization on yield and active constituents of Thymus vulgaris $\mathrm{L}$. under North Sinai conditions. Research Journal of Agriculture and Biological Sciences, 5(4): 555-565.

Aziz Eman E. (2004). Comparative study on the effect of ammonium nitrate and ammonium sulphate through the application of poultry manure on the produtivity of Achillea millefolium L. plants. Arab Univ. J. Agric. Sci., Ain Shams Univ., Cairo, 12(1). 371 389.

Aziz Eman E. and Taalab A.S.M. (2004). Dragonhead plants (Dracocephalum moldavica) responses to salt stress and different sources of sulfur. Egypt J. Appl. Sci. 19(5):239-257.

Aziz Eman E., El-Danasoury M.M. and Craker L.E. (2010). Impact of sulfur and ammonium sulfate on dragonhead plants grown in newly reclaimed soil. Journal of Herbs, Spices \& Medicinal Plants, 16: 126-135.

Baggio C.H., Freitas C.S., Nhaducue P.F., Rieck L. and Marques M.C.A. (2002). Action of crude aqueous extract of leaves of Achillea millefolium L. (Compositae) on gastrointestinal tract. Rev. Bras. Farmacogn., 12: 31-33.

Balbach A. (1995). As plantas curam, Vida Plena, Itaquaquecetuba. p.218.

Blumenthal M., Goldberg A. and Brinckmann J. (2000). Herbal medicine. Expanded 
commission E monographs. Newton: Integrative Medicine Communications, 419423.

Candan F., Unlu M., Tepe B., Daferera D., Polissiou M., Sokmen A. and Akpulat A. (2003). Antioxidant and antimicrobial activity of the essential oil and methanol extracts of Achillea millefolium subsp. Millefolium Afan. (Asteraceae). Journal of Ethnopharmacology, 87:215-220.

Egyptian Pharmacopoeia (1984). General Organization for Government Printing Office,. pp.31-33, Ministry of Health, Cairo, Egypt.

El-Sayed A.A., Sidky, Mahassen M.A., Mansour H.A. and Mohsen, Maie M.A. (2009). Effect of organic fertilizer and Egyptian rock phosphate on the growth, chemical composition and oil production of tarragon (Artemisia dracunculus L.). Journal of Productivity and Development, 14(1): 87110.

Gosh P.K., Hati K.M., Mandal K.G., Misra A.K., Chaudhary A.S. and Bandyopadhyay K.K. (2000). Sulphur nutrition in oilseeds and oilseed-based cropping systems. Fertilizer News, 45(8): 27-40.

Grth M. and Czygan F. (1999). Variation in essential oil composition and chiral monoterpenes of Achillea millefolium. J. Essent. Oil Res.11: 681 - 687.

Guenther E. (1961). The Essential Oils. Vol 3, p.400. Van Nostrand Comp. Inc., New York, U.S.A.

Haneklaus S., Hoppe L., Bahadir M. and Schnug E. (1997). Sulphur nutrition and alliin concentrations in Allium species. In: Cram W.J., L.J. Dekok, I. Stulen, C. Brunold and H. Rennenberg., eds. Sulphur metabolism in higher plants. Molecular, ecophysiological and nutritional aspects. Leiden, Backhuys Publishers, 367p.

Hendawy S.F., Ezz El-Din, Azza A., Aziz Eman E. and Omer E.A. (2010). Productivity and oil quality of Thymus vulgaris L. under organic fertilization conditions. Ozean Journal of Applied Sciences, 3(2):203- 216.

Hofmann L. and Frtiz D. (1993). Genetical, ontogenetical and environmental caused variability of the essential oil of different types of the Achillea millefolium Lamplex. Acta Horticulture, 330: 147-155.

Hornok L. (1974). The effect of nutrients supply on peppermint yields and essential oil content. Kerteszeti Egyetem Kozlemenyei, 38(6): 73 -82 Kertezeti Egyetem, Budapest, Hungary. (Hort. Abst. 1975, 45(12): 9999).

Jackson M.L. (1973). Soil Chemical Analysis. Prentice-Hall, Inc. Englewood Cliffs. N.J..

Lancaster J.E., Farrout J. and Show M.L. (2001). Sulfur nutrition affects cellular sulfur, dry weight distribution, and bulb quality in onion. Jour. Amer. Soc. Hort. Sci. 126(2):164-168.

Lawless J. (1992). The Encyclopaedia of Essential Oils. Element Book. Ltd. Long Mead, Shoftesbury, Dorest. Great Britain.

Lin L.T., Liu L.T., Chiang L.C. and Lin C.C. (2002). In vitro anti-hepatoma activity of 15 natural medicines: Canada. Phytotherapy Research, 16: 440-444.

Mitich L.W. (1990). Intriguing world of weeds: Yarrow- the herbal of Achilles. Weed Technology, 4: 451-453.

MSTAT-C (1988). MSTAT-C, a microcomputer program for the design, arrangement and analysis of agronomic research. Michigan State University, East Lansing, MI.

Nilforoushzadeh M.A., Shirani-Bidabadi L., Zolfaghari-Baghbaderani A., Saberi S., Siadat A.H. and Mahmoudi M. (2008). Comparison of Thymus vulgaris (thyme), Achillea millefolium (yarrow) and propolis hydroalcoholic extracts versus systemic glucantime in the treatment of cutaneous leishmaniasis in balb/c mice. J Vector Borne Dis, 45: 301-306.

Ragažinskienè O., Rimkienë S. and Sasnauskas V. (2005). Vaistiniø augal $\varnothing$ enciklopedija. Kaunas: Lututë.

Ram D., Ram M. and Singh R. (2006). Optimization of water and nitrogen application to menthol mint (Mentha arvensis L.) through sugarcane trash mulch in a sandy loam soil of semi-arid subtropical climate. Bioresource Technology, 97: 886-893.

Rodrigo M.C., Ginestar J., Bois M. and Ramoo C. (2005). Evaluation of rapid methods for nitrate plant sap analysis of globe artichoke grown in sand culture. Acta Hort. 697:393397.

Rohloff J., Skagen E.B., Steen A.H. and Iversen T.H. (2000). Production of Yarrow (Achillea millefolium L.) in Norway: Essential oil content and quality. J. Agric. Food Chem., 48: 6205-6209.

Sampson B., Kovar I.Z., Rauscher A., Fairweather-Tait S., Beattie J., McArdle H.J., Ahmed R. and Green C. (1997). A case 
of hyperzincanemia with functional zinc depletion: A new disorder. Pediatric Res., 42: 219-25.

Santhi R. and Selvakumari G. (2000). Use of organic sources of nutrients in crop production. In: theme papers on integrated nutrient management (Ed.) Kannaiyan et al., published by Tamil Nadu Agric. Univ. and Tamil Nadu Deptartment of Agriculture, 87101.

Seng Y.C. (1986). Studies on the preparations and properties of natural rubber coated slow release fertilizer. Ph.D. Thesis, Fac. Agric. Ghent, Belgium.

Sifola Maria I. and Barbieri G. (2006). Growth, yield and essential oil content of three cultivars of basil grown under different levels of nitrogen in the field. Scientia Horticulturae, 108 : 408-413.

Snyman H.G., Jong D.E. and Aveling T.A.S. (1998). The stabilization of sewage sludge applied to agricultural land and the effects on maize seedlings. Water Sci. Technol., 38(2): 87-95.

Stamford N.P., Freitas A.D., Ferraz D.S. and Santos C.E. (2003). Nitrogen fixation and growth of cowpea (Vigna unguiculata) and yam bean (Pachyrhizys erosus) in a sodic soil as affected by gypsum and sulfur incoculated with Thiobacillus and Rhizobial inculation. Tropical Grasslands, 37(1):11-9.

Sweetman S.C. (2002). (Ed). 33rd. Martindale: The Complete Drug Reference. Pharmaceutical Press, London, p.1572.

Tozyo T., Yoshimura Y., Sakurai K., Uchida N., Takeda Y., Nakai H. and Ishii H. (1994). Novel antitumor sesquiterpenes in Achillea millefolium. Chemical \& Pharmaceutical Bulletin, 42: 1096-1100.

Zheljazkov V.D., Cantrell Ch.L., Ebelhar M.W., Rowe D.E. and Coker Ch. (2008). Productivity, oil content, and oil composition of sweet basil as a function of nitrogen and sulfur fertilization. Hortscience, 43(5):14151422 .

\section{تأثير التسميد العضوي, الكبريتي و النيتروجينى علي إنتاج الزيت الطيار لنبات الآثيليا تحت ظروف الأراضي الرملية المستصلحة الزئية (Achillea millefolium L.)}

$$
\begin{aligned}
& \text { السعدي تحمد بدوي - إيمان إبراهيم عزيز* - سعد ميلاد نيقولا - هند فؤاد إسماعيل* }
\end{aligned}
$$

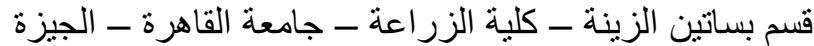

$$
\begin{aligned}
& \text { * قسم زر اعة و إنتاج النباتات الطبية و العطرية ــ المركز القومي للبحوث ــ الدقى ـ القاهرة }
\end{aligned}
$$

\section{ملخص}

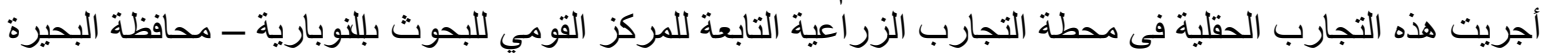

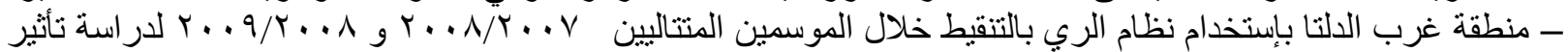

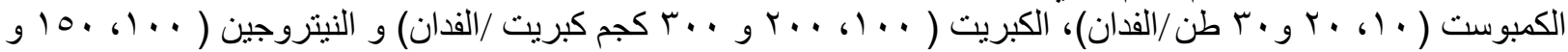

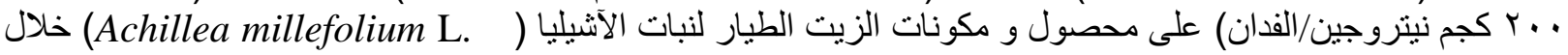
الحشات المختلفة

ينميز الزيت الطيار للقمم الز هرية لنبات الآشيليا بإحتو ائه على

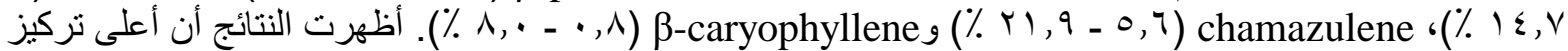

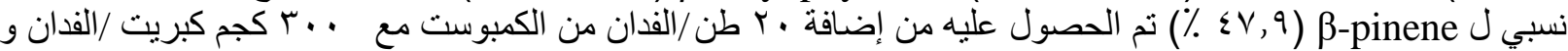

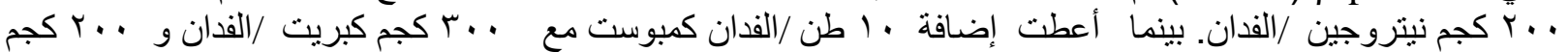

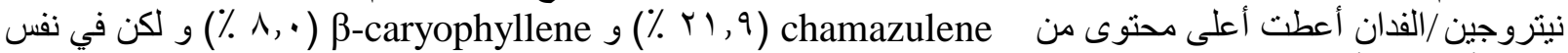

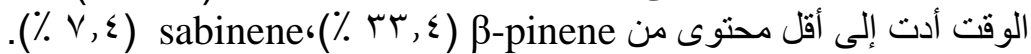

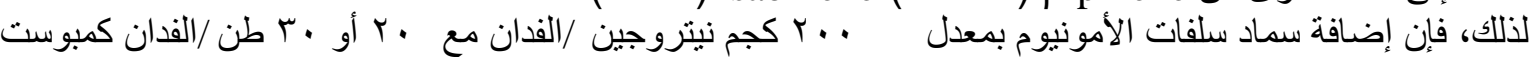

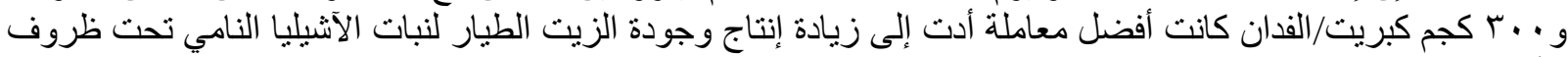

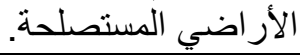

